\title{
The Spreading of Flaviviruses over the Continental Divide: a Challenge for Serologic Diagnostics
}

Sissy Therese Sonnleitner ${ }^{1 *}$, Josef Simeoni² ${ }^{2}$ Raphaela Baumgartner ${ }^{1}$, Roland Zelger $^{3}$, Angelika Prader ${ }^{3}$, Grazia Piccolin $^{4}$, Norbert Nowotny $^{5,6}$ and Gernot Walder ${ }^{1,7}$

${ }^{1}$ Dr. Gernot Walder $\mathrm{GmbH}$, Außervillgraten, Austria

${ }^{2}$ Department of Health of the Autonomous province of South Tyrol, Bozen, Italy

${ }^{3}$ Research Center for Agriculture and Forestry Laimburg, Pfatten, Italy

${ }^{4}$ Unità Locale Socio Sanitaria, Belluno, Italy

${ }^{5}$ Viral Zoonoses, Emerging and Vector-Borne Infections Group, Institute of Virology, University of Veterinary Medicine, Vienna, Austria

${ }^{6}$ Department of Microbiology and Immunology, College of Medicine and Health Sciences, Sultan Qaboos University, Muscat, Oman

${ }^{7}$ Department of Hygiene, Medical Microbiology and Social Medicine, Innsbruck Medical University, Innsbruck, Austria

\begin{abstract}
West Nile virus and Usutu virus are spreading over Europe. The last confirmed outbreaks of West Nile virus took place in Greece in 2011 and Northern Italy, 2012. A serious outbreak of Usutu virus in birds occurred in Germany in 2010 and 2011, indicating an increased risk of Usutu virus infections in humans. Sera of 1,607 healthy blood donors in the Tyrols (Austria and Italy) were investigated for the presence of $\lg \mathrm{G}$ antibodies for tick-borne encephalitis virus and West Nile virus by ELISA as well as for Usutu virus by in-house immunofluorescence assay. Furthermore, 2,571 mosquitoes were trapped in the study area and screened for flaviviral and West Nile-specific RNA by RT-PCR. Initial results indicated seroprevalence rates of $46.2 \%$ for West Nile virus in North Tyrol and $0.5 \%$ in South Tyrol as well as $16.5 \%$ and $0.3 \%$ for Usutu virus, respectively, which turned out to be false positive cross-reactions with antibodies against tick-borne encephalitis virus or other vaccine-associated flaviviral antibodies by adjacent neutralization assays. Actually, neutralizing antibodies against West Nile virus were found in five sera ( $0.5 \%$ seroprevalence), against Usutu virus in one serum ( $0.1 \%$ seroprevalence). This study shows that the Tyrolean population does not come into immunoreactive contact with West Nile virus or Usutu virus and that no flavivirus could be detected in trapped mosquitoes. Furthermore, the study provides cross-reactivities of up to $58.8 \%$ (460 of 782 ) of flaviviral antibodies in ELISA-testing and up to $21.5 \%$ (168 of 782 ) in immunofluorescence assay and that cross-reactivity increases with increasing number of vaccinations against Flaviviruses. This study illuminates the degree of cross-reactivities of flaviviral antibodies in a healthy blood donor collective and shows the difficulties in the differentiation of flaviviral antibodies in serologic diagnostics.
\end{abstract}

Keywords: West Nile virus; Usutu virus; Serology; Cross-reactions; Diagnostics; Tyrols; Austria; Europe

\section{Introduction}

West Nile virus (WNV) and Usutu virus (USUV) are mosquitoborne, mainly bird-associated flaviviruses and members of the Japanese encephalitis virus (JEV) complex [1,2], closely related to other human pathogens, such as dengue virus (DENV), yellow fever virus (YFV) and tick-borne encephalitis virus (TBEV).

Over the last several years, WNV has gained importance as an emerging human pathogen in Eastern Europe that has been spreading westward along the Danube. Recently, West Nile virus (WNV) was proven to be present in the neighboring countries of Austria, such as Italy, Hungary and the Czech Republic [3-5], as well as in eastern parts of Austria [6], where it was detected in birds by RT-PCR. The last confirmed cases of West Nile fever in Europe occurred in Greece in 2011 [7] and Venice/Italy in summer 2012 [8].

The first recognized outbreak of USUV outside of Africa occurred in Vienna, Austria in 2001, where it caused deaths in blackbirds (Turdus merula) and great gray owls (Strix nebulosa) [9]. In the following years, Chvala et al. [10] demonstrated overwintering of USUV in local birdmosquito cycle, where it is well-established now. Furthermore, USUVspecific RNA was also detected in birds or mosquitoes in Hungary, Switzerland, Italy and Spain $[3,11,12]$ and one great outbreak with hundreds of dead birds took place in Germany in 2011 and 2012 [13]. Wild birds are the principal reservoir for WNV and USUV and migratory birds play a key role in the introduction of those viruses into new areas.
Aedes albopictus, the Asian Tiger Mosquito, and seven respectively one further possible vectors of WNV and USUV were found in the study area and gave reason for increased surveillance and establishment of diagnostic tools for those invasive viruses in the study area.

The aim of this study was to determine seroprevalence rates against TBEV, WNV and USUV in the local population of the Tyrols, to investigate whether testing by ELISA provides sufficient specifity to identify the causative agent and which approaches are suitable for the early detection of a new flavivirus invading an Alpine area.

\section{Material and Methods}

The area of investigation represents the European region of the Tyrols, as shown in figure 1. Drau (East Tyrol), Inn and Lech (North Tyrol, both of which are parts of Austria) are tributaries of the Danube which drains to the Black Sea, whereas the Etsch drains directly to the

${ }^{*}$ Corresponding author: Sonnleitner Sissy Therese, MSc, Dr. Gernot Walder $\mathrm{GmbH}$, Außervillgraten, Unterwalden 30, A-9931 Ausservillgraten, Austria, Tel: 00434843 20065; Fax: 00434843 20093; E-mail: sissyson@gmx.at

Received December 10, 2012; Accepted January 26, 2013; Published January 29, 2013

Citation: Sonnleitner ST, Simeoni J, Baumgartner R, Zelger R, Prader A, et al (2013) The Spreading of Flaviviruses over the Continental Divide: a Challenge for Serologic Diagnostics. J Med Microb Diagn S3: 002. doi:10.4172/2161-0703.S3-002

Copyright: () 2013 Sonnleitner ST, et al. This is an open-access article distributed under the terms of the Creative Commons Attribution License, which permits unrestricted use, distribution, and reproduction in any medium, provided the original author and source are credited. 
Citation: Sonnleitner ST, Simeoni J, Baumgartner R, Zelger R, Prader A, et al. (2013) The Spreading of Flaviviruses over the Continental Divide: a Challenge for Serologic Diagnostics. J Med Microb Diagn S3: 002. doi:10.4172/2161-0703.S3-002

Adriatic Sea. A collective of 1,607 healthy blood donors between 20 and 60 years of age, representing the total population of the study area regarding gender, profession, and altitude of residence, gave informed consent, answered a questionnaire, and donated $2 \mathrm{ml}$ of blood for study purposes. A precise description of the collective is given in table 1.

In preliminary tests, the cross-reactivities of two commercially available enzyme-linked immunosorbent assays (ELISAs) and one immunofluorescence assay (IFA) with TBEV antibodies were assessed using the sera of 89 children under five years of age who had been vaccinated against TBEV and whose sufficient immunity had been proven. In the main study, 1,607 sera were tested for the presence of antibodies to WNV, employing an ELISA distributed by MRL

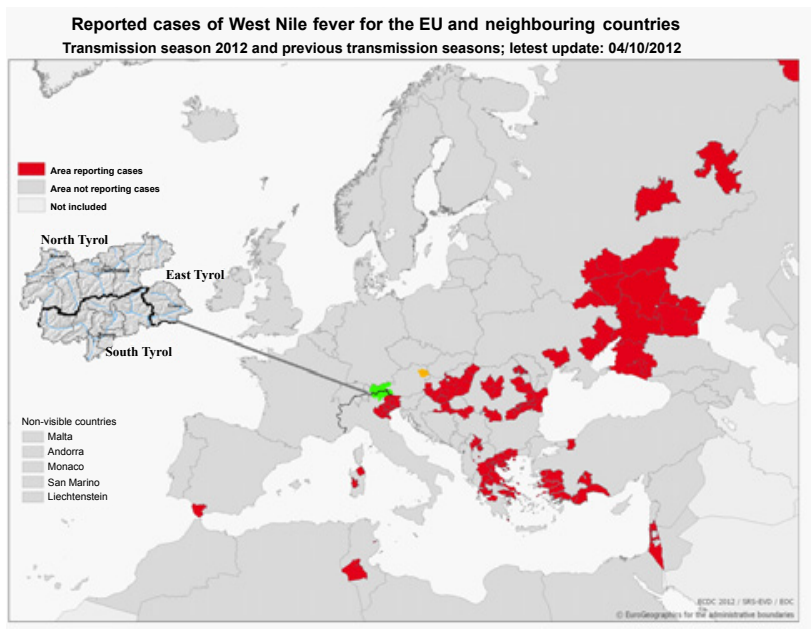

Figure 1: European Center for Disease Control (2012) West Nile Fever epidemiological data. The study area of the Tyrols and its location in Europe are shown in green. Areas with recent outbreaks of West Nile fever are shown in red. One area in orange shows recent detection of West Nile virus in Vienna/Austria and was given us by oral communication (Nowotny, Vienna, Austria).

\begin{tabular}{|c|c|c|c|c|}
\hline District & Inhabitants & $(\%)$ & Samples & $(\%)$ \\
\hline Reutte & 31,584 & 2.8 & 58 & 3.6 \\
\hline Upper Inn valley & 94,457 & 8.4 & 120 & 7.4 \\
\hline Central Inn valley & 268,323 & 23.6 & 411 & 25.5 \\
\hline Lower Inn valley & 227,727 & 20 & 317 & 19.7 \\
\hline Drau valley & 58,657 & 5.1 & 100 & 6.2 \\
\hline Danube Area & 681,757 & 60 & 1,006 & 62.7 \\
\hline Pustertal & 64,893 & 5.7 & 95 & 5.9 \\
\hline Eisack valley & 62,199 & 5.5 & 79 & 4.9 \\
\hline Upper Etsch valley & 204,629 & 18 & 277 & 17.2 \\
\hline Lower Etsch valley & 122,568 & 10.8 & 144 & 9 \\
\hline Unknown residence & & & 6 & 0.4 \\
\hline Etsch area & 454,289 & 40 & 601 & 37.3 \\
\hline Male* $^{*}$ & 558,198 & 48.9 & 801 & 50 \\
\hline Female* & 582,644 & 51.1 & 80 & 50 \\
\hline Aged $20-39$ years & 352,738 & 54.9 & 835 & 52 \\
\hline Aged $40-60$ years & 290,1 & 45.1 & 772 & 48 \\
\hline$>10,000$ inhabitants ${ }^{*}$ & 378,248 & 33.2 & 444 & 27.7 \\
\hline$<10.000$ inhabitants $^{*}$ & 762,614 & 66.8 & 1,157 & 72.3 \\
\hline Altitude $>1,200 \mathrm{~m}^{*}$ & 80,333 & 7 & 121 & 7.6 \\
\hline Altitude $<1.200 \mathrm{~m}^{*}$ & $1,060,509$ & 93 & 1,48 & 92.4 \\
\hline
\end{tabular}

*Six participants did not specify the place of residence or gender

Table 1: Overview of the number of Tyroleans and the number of tested samples in this study, divided into particular river valleys, gender, age groups, urban and rural areas and the altitude of the river valleys in meters above sea level.
Diagnostics, Cypress, CA, according to the manufacturer's guidelines. Positive results were confirmed by a neutralization assay elsewhere [14]. Sera were tested for antibodies to TBEV using a commercially available ELISA (Enzygnost, Siemens, Vienna, Austria), according to the manufacturer's recommendations. Sera yielding a titer of 15 arbitrary units or higher were rated positive. Neutralization assays to TBEV were carried out by the Austrian reference center in Vienna according to their standard procedures. Sera were subjected to a neutralization test against TBEV when the proband: 1.) is a resident of the catchment area of the Danube, 2. ) was found to be positive by ELISA and did not have a TBEV vaccination history and 3.) is a resident of the catchment area of the Etsch and was found to be positive by ELISA, independently of previous TBEV vaccinations. Furthermore, all 1,607 sera were tested for IgG antibodies against USUV by in-house immunofluorescence assays (IFA) and re-tested with an in-house serum neutralization assay. The obtained seroprevalence data were subjected to a Chi-squared test. Differences were considered to be statistically significant when the $p$-value was $\leq 0.05$ (SPSS 12.0).

\section{Immunofluorescence assay}

For the production of immunofluorescence assays, $25 \mathrm{~cm}^{2}$ flasks with monolayers of Vero B4 cells (no. ACC-33, DSMZ) were infected with one $\mathrm{ml}$ of USUV (strain Vienna, GenBank accession no. AY453411) and incubated at $36^{\circ} \mathrm{C}$ by gently shaking the flask every ten minutes. After one hour, cultures were overflowed with Medium199 (Gibco, USA), including 5\% of inactivated fetal calf serum (Gibco, USA). When first cytopathic effects were detected 3-4 days post infection, IFA was done by trypsinizing infected cell cultures and fixing infected cells with ice cold 1:1 acetone-methanol mixture on IFA-slides. Identification of cultured strain, regular controls of infections in cell cultures and screening of mosquitoes were performed by RT-PCR $[11,15]$ and subsequent sequencing. IFA-slides against USUV were tested by using polyclonal human serum with known cross-reactions against flaviviruses of different serogroups.

The local cut-off titre for screening against IgG antibodies was set at 1:64 with a well-characterized low-risk collective, consisting of a cohort of 145 blood donors out of the 1,607 collected sera. Blood donors of the low-risk collective were Tyroleans living higher than 1,400 $\mathrm{m}$ above sea level. None of them had an obvious risk of mosquito exposition, travelling background or an employment below 1,400 m altitude. Among the low-risk collective of 145 blood donors, 3.4\% were positive for IgG antibodies against USUV at a titre of $1: 32$ and $1.4 \%$ were positive at 1:64. Thus, according to criteria of the WHO, the cut-off titre was set at 1:64 for IgG. Sera were assessed positive if the fluorescence signal was strong at a dilution of 1:64 or above and negative if the signal was weak or negative at a titre of 1:64. All positive sera were confirmed by serum neutralization assay. Investigations concerning the cut-off titre of IgM antibodies was ascertained the same way and resulted in a titre of 1:128.

\section{Serum neutralization assay for USUV}

For the serum neutralization assay (SNA), cell culture supernatant of USUV was used, and infectivity titrations of this suspension was carried out by plaque assay using Vero B4 cells (no. ACC-33, DSMZ). The test was performed in 96 flatwell microtitre plates. Serum samples were titrated in duplicate in twofold dilution steps (50 $\mu$ l per well), starting at a dilution of 1:8 in Medium199 containing 3\% fetal calf serum. Equal volumes of virus and serum dilutions in Medium199 were mixed to give a final virus concentration of 1,000 PFU Plaque forming units (PFU)/ml. These mixtures were incubated for 1 hour at $36^{\circ} \mathrm{C}$. A 
Vero B4 cell suspension ( 1 to 10 cells in a volume of $50 \mu \mathrm{l}$ ) was then added and the cells were incubated at $36^{\circ} \mathrm{C}$ for 5 days.

The SNA titres were expressed as the reciprocal of the serum dilution that was able to suppress virus infection to such an extent that no cytopathic effects could be detected in the supernatant in phase contrast microscopy. The test was repeated twice and the results averaged. In each test, titrations of virus controls in the absence of antibodies and one negative serum control were included.

\section{Sampling of mosquitoes and PCR}

From May to September 2011, adult mosquitoes were caught in 18 municipal areas: North Tyrol: Leutasch (1), Nassereith (2), Igls (3), Pflach (4), Prutz (5), Völs (6), Waidring (7), Walchsee (8); East Tyrol: Strassen (9); South Tyrol: Aldein (10), Bozen (11), Bruneck (12), Eppan (13), Freienfeld (14), Gummer (15), Neumarkt (16), Salurn (17), St. Martin in Passeier (18) (Figure 1). The mosquitoes were collected with dry-ice $\left(\mathrm{CO}_{2}\right)$ baited Encephalitis Virus Surveillance (EVS) light traps from 5:00 PM to 9:00 AM. The mosquitoes were killed with $\mathrm{CO}_{2}$ and transported to the laboratory on dry ice. Morphological examination was carried out according to Mohrig [16] and Becker et al. [17]. During morphological examination, mosquitoes were pooled to 1 to 20 individuals according to species, sampling site and sex and stored at $-70^{\circ} \mathrm{C}$ afterwards. For extraction of RNA, mosquitoes were homogenized in $1 \mathrm{ml}$ Medium 199 (Gibco, USA), whereof $140 \mu$ l were used for extraction with Qiamp Viral RNA mini Kit (Qiagen, Hilden, Germany) and investigated for the presence of flaviviral and West Nile virus-specific RNA by PCR $[11,15]$. For the RT-PCR, a commercial kit was used (IScript ${ }^{\mathrm{TM}}$ One-step RT-PCR kit With $\mathrm{SYBR}^{(\mathrm{R})}$ Green, BioRad Laboratories, Hercules, CA). Briefly, $12.5 \mu \mathrm{l}$ of the twofold reaction buffer were mixed with each $0.25 \mu$ of Reverse transcriptase and Primers $(100 \mathrm{pmol} / \mu \mathrm{l}), 1.8 \mu \mathrm{l}$ of water and $10 \mu \mathrm{l}$ of the particular template. PCR was performed on the following schedule: $50^{\circ} \mathrm{C}$ for 10 min, $95^{\circ} \mathrm{C}$ for $5 \mathrm{~min}$ followed by $32 \mathrm{cycles}$ of $95^{\circ} \mathrm{C}$ for $10 \mathrm{sec}$ and $59^{\circ} \mathrm{C}$ for $30 \mathrm{sec}$ on a real-time thermocycler (Biorad CFX 96). Comparative data of seroprevalence were tested with a chi-squared test. Differences were considered statistically significant when $P$ was $\leq 0.05$.

\section{Results}

Detailed results of the seroepidemiologic survey for TBEV, WNV and USUV IgG antibodies are shown in table 2. Seroprevalence rates against TBEV was $67.2 \%$ in the Danube area (775 of 1,006) versus significantly lower $2.0 \%$ in the Etsch area $(7$ of $601 ; p<0.05)$. In combination with the analysis of the questionnaires, efficacy of immunization were comparable $96.2 \%$ and $91.0 \%$ in both study areas and wild virus infections with TBEV were $1.9 \%(19$ of 1,006$)$ in the north and $0.2 \%$ in the south ( 1 of 601$)$.

Seroepidemiological results of the WNV-ELISA showed a similar picture, even though rates were lower with $45.3 \%$ positive donors (456 of 1,006$)$ in the north and $0.7 \%$ in the south $(4$ of 601$)$. The subsequent neutralization assay of all West Nile-positive sera effectively showed five West Nile virus-positive blood donors in the catchment area of the Danube, which means $0.5 \%$ and none in the catchment area of the Etsch. In detail, two probands yielded titers of 1:20, one of which had been to Israel and other countries of the Middle East on several occasions, and the other one recalled holidays to Egypt during which he had suffered a febrile illness. Three probands exhibited neutralization titers of 1:10 (one had reported previous travels to Mediterranean countries, one had been in eastern Austria repeatedly, and the third patient did not provide information on previous activities outside of Tyrol). All samples containing neutralizing antibodies to WNV also showed high ELISA titers to TBEV.

Of 1,607 sera tested against USUV, 10.5\% (168) showed clear fluorescence in IFA. Of these 168 blood donors, 166 (98.2\%) were residents of the catchment area of the Danube and two (1.2\%) were residents of the catchment area of the Etsch. One blood donor (0.06\%) neutralized in subsequent SNA with a titre of $1: 50$, who was a resident of East Tyrol/catchment area of the Danube and who had been vaccinated with all three possible vaccines against flaviviruses (TBEV, YFV and JEV). Remarkably, the proband reported one episode of encephalitis and severe febrile illness following mosquito exposure in Northern Italy. Herpesviruses, Phleboviruses, neurotropic Bunyaviruses and infection with TBEV had then been ruled out. Up to now, the cause of infection remained unclear.

Cross-reactivity between TBEV and WNV in ELISA was 58.8\% (460 of 782). Of these TBEV-positive sera, $21.5 \%$ (168 of 782) showed clear fluorescence in the USUV - IFA, which is a significantly lower $(p<0.05)$ cross-reactivity. Figures 2 and 3 show that cross-reactivity increases with increase in number of different flaviviral vaccinations, as well as with increasing numbers of booster vaccinations against TBEV. Blood donors, who had been immunized nine or more times against TBEV $(\mathrm{n}=13)$ significantly more often reacted in WNV-ELISA $(p<0.05)$, but not in USUV-IFA $(p<0.05)$. Figure 4 shows that cross-reactivity was higher in blood donors who had been immunized recently (3 to 12 months ago) than in blood donors, whose last booster vaccination was one to five years or more than five years ago. Cross-reactivities against USUV were significantly higher in blood donors boostered recently

\begin{tabular}{|c|c|c|c|c|c|c|c|c|c|}
\hline District & No. of samples & TBEV ELISA & $(\%)$ & WNV ELISA & (\%) & USUV IFA & (\%) & WNV SNT (\%) & USUV SNT (\%) \\
\hline Reutte & 58 & 34 & $(58.6)$ & 16 & $(27.6)$ & 10 & $(17.2)$ & $1(2.0)$ & 0 \\
\hline Upper Inn valley & 120 & 81 & $(67.5)$ & 43 & $(35.6)$ & 26 & $(21.7)$ & $1(1.2)$ & 0 \\
\hline Central Inn valley & 411 & 343 & $(83.5)$ & 207 & $(51.3)$ & 64 & $(15.6)$ & $1(0.9)$ & 0 \\
\hline Lower Inn valley & 317 & 242 & $(76.3)$ & 153 & $(48.2)$ & 53 & $(16.7)$ & $2(0.8)$ & 0 \\
\hline Drau valley & 100 & 75 & $(75.0)$ & 37 & $(14.2)$ & 13 & $(13.0)$ & 0 & 1 \\
\hline Danube Area & 1,006 & 775 & $(77.0)$ & 456 & $(45.3)$ & 166 & $(16.5)$ & $5(0.5)$ & 0 \\
\hline Pustertal & 95 & 0 & $(0)$ & 0 & (0) & 0 & $(0.0)$ & 0 & 0 \\
\hline Eisack valley & 79 & 4 & $(5.1)$ & 1 & $(1.3)$ & 1 & (1.3) & 0 & 0 \\
\hline Upper Etsch valley & 277 & 2 & $(0.7)$ & 3 & $(1.1)$ & 1 & $(0.4)$ & 0 & 0 \\
\hline Lower Etsch valley & 144 & 1 & $(0.7)$ & 0 & (0) & 0 & $(0)$ & 0 & 0 \\
\hline Unknown residence & 6 & 0 & (0) & 0 & (0) & 0 & (0) & 0 & 0 \\
\hline Etsch area & 601 & 7 & $(1.2)$ & 4 & $(0.7)$ & 2 & $(0.3)$ & $0(0)$ & 0 \\
\hline Both study areas & 1,607 & 782 & $(48.7)$ & 460 & $(28.6)$ & 168 & $(10.5)$ & $5(0.4)$ & $1(0.06)$ \\
\hline
\end{tabular}

Table 2: Seroepidemiologic results of 1,607 sera investigated against TBEV and WNV by ELISA and against USUV by in-house IFA. 


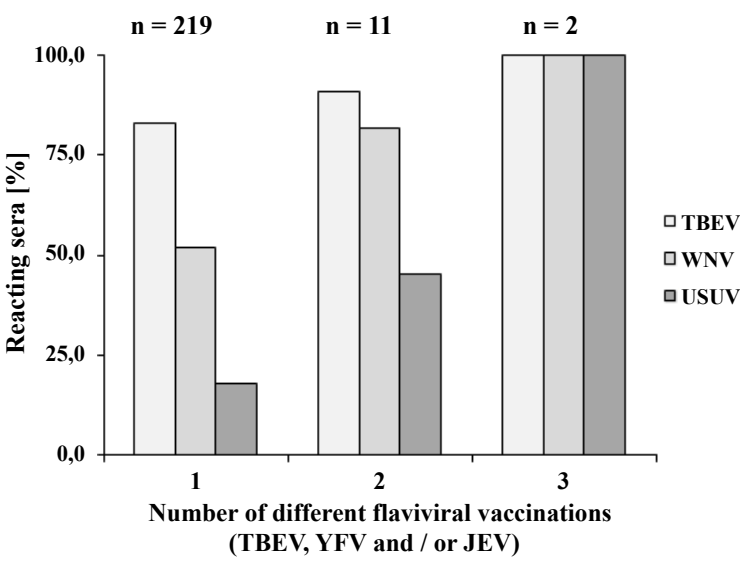

Figure 2: Increasing percentage of serologic cross-reactions with increasing number of different vaccines against Flaviviruses (TBEV, YFV or JEV).

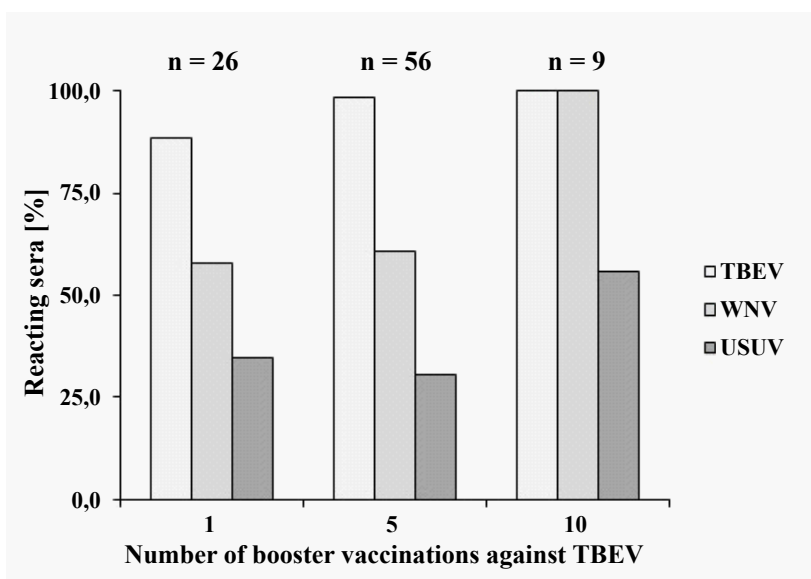

Figure 3: Increasing percentage of serologic cross-reactions with increasing number of immunizations against TBEV.

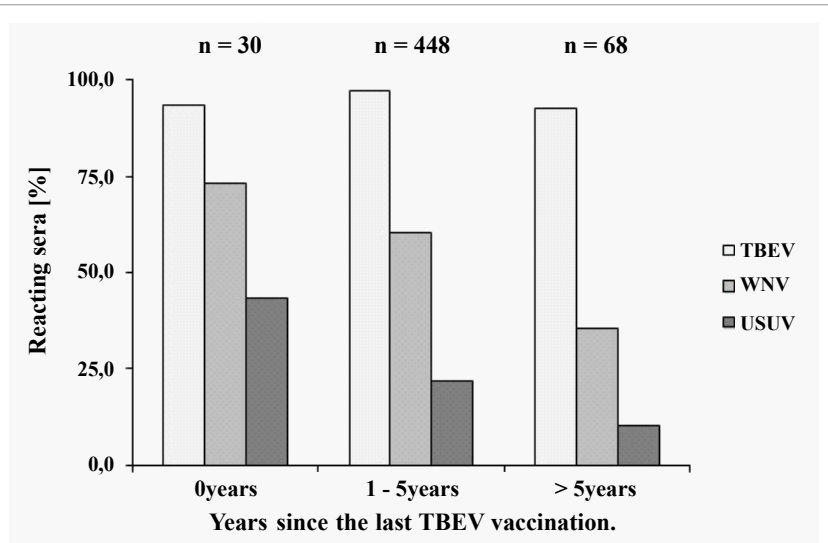

Figure 4: Increasing percentage of serologic cross-reactions with decreasing time span between serologic test and the last booster vaccination against TBEV.

against TBEV compared to those who had a time span of one or more years between serologic testing and vaccination (43.3 versus 21.9 and $10.3 ; p<0.05)$. Cross-reactivities against WNV were significantly higher in blood donors boostered recently compared to those who had a time span of more than five years, ( 73.3 versus $35.3 \%$; $p<0.05$ ), but only insignificantly higher cross-reactivities compared with those who had been boostered one to five years ago ( 73.3 versus $60.5 \%$; $p<0.05$ ).

When omitting probands whose travel history make infections with WNV probable, the cut-off titre for specific neutralization against WNV was set at 1:10 according to WHO-guidelines.

Cross-reactivities with TBEV, WNV or USUV were lower in blooddonors who had only been vaccinated against YFV. Of 31 blood donors in the whole study area without a second flaviviral vaccination, only three (9.7\%) donors reacted with TBEV, one with USUV (3.2\%) and zero with WNV. Probability of cross-reactivity was insignificantly reduced in blood donors with wild virus infections of TBEV (47.4 versus $60.6 \%$ for WNV and 15.8 versus $21.2 \%$ for USUV).

During this investigation, two cases of wild virus infection with TBEV occurred in North Tyrol, which were available for IgMcrossreactivity testing by IFA. Neither was reactive with WNV, USUV, JEV, YFV or DENV.

\section{Sampling of mosquitoes}

Sampling of mosquitoes at 18 sampling sites throughout the study area resulted in 2,571 adult mosquitoes, with 1,254 Aedes, amongst others Aedes albopictus (48.8\%), 640 Culex (24.9\%), 303 Coquillettidia (11.8\%), 252 Ochlerotatus (9.8\%), 73 Culiseta (2.8\%) and 49 Anopheles (1.9\%). Details of the mosquito sampling are given in table 3 including evidently competent vectors for WNV or USUV [5, 18-22]. PCR testing of all 195 mosquito-pools for flaviviral and West Nile-specific RNA negative in all 195 mosquito-pools. Aedes albopictus was sighted in summer 2010 in the city of Bozen, for the first time. In summer 2011, the mosquito had been dispersed throughout the city of Bozen and could broaden its habitat in the surroundings of Bozen in summer 2012. Of the trapped mosquitoes, eight species are evidently potential vectors for West Nile virus and, at least, two for Usutu virus, as shown in table 3.

\section{Discussion}

Our investigation failed to prove any autochthonous infection with WNV or USUV in the study area. In all probability, both probands yielding a neutralization titer of 1:20 in SNA against WNV acquired the infection abroad; all other results are most likely false positive due to cross-reactions with TBEV. At the moment, West Nile fever must be considered a mere travel-related disease in the Tyrols (Austria/Italy). However, competent vectors are plenty in our study area as well as competent reservoir hosts. This and the fact, that the Tyrols lie within the transit routes of migratory birds provides at least a theoretical risk of introduction. Establishment of WNV or USUV in a geographic area has serious consequences for security of blood transfusions and a vast range of derived blood products. Thus, the emergence of novel flaviviruses requires monitoring. Such monitoring can be done in three complementary ways: By monitoring clinical cases, by investigating vectors and by seroepidemiological surveys. Each of these three ways has its particular limitations, which can be overcome by a combined approach.

Assessment by clinical monitoring requires a raised level of awareness among physicians, veterinary doctors and game wardens as well as sufficient diagnostic tools. In the acute stage of illness, careful investigations of the reaction panel of IgM antibodies titre against the local flaviviruses, preferably with IFA, may lead the way. This should be 


\begin{tabular}{|c|c|c|c|c|c|c|c|c|}
\hline & No. of samples & Frequency (\%) & female & male & unknown sex & Pan Flavi & WNV & source \\
\hline Aedes vexans & 995 & 38.7 & 955 & 0 & 40 & negative & negative & [21] \\
\hline Culex pipiens /torrentium & 619 & 24.1 & 530 & 0 & 89 & negative & Negative & {$[5,21]$} \\
\hline Ochlerotatus /Aedes cantans & 550 & 21.4 & 14 & 0 & 536 & negative & negative & [22] \\
\hline Coquillettidia richardii & 301 & 11.7 & 243 & 0 & 58 & negative & negative & {$[23,24]$} \\
\hline Aedes albopictus & 80 & 3.1 & 32 & 22 & 26 & negative & negative & [21] \\
\hline Culiseta annulata & 73 & 2.8 & 14 & 0 & 59 & negative & negative & \\
\hline Anopheles claviger/petragnani & 23 & 0.9 & 23 & 0 & 0 & negative & negative & \\
\hline Aedes sp. & 20 & 0.8 & 0 & 0 & 20 & negative & negative & \\
\hline Culex sp. & 18 & 0.7 & 0 & 17 & 1 & negative & negative & \\
\hline Anopheles claviger & 16 & 0.6 & 16 & 0 & 0 & negative & negative & \\
\hline Anopheles plumbeus & 10 & 0.4 & 5 & 0 & 5 & negative & negative & [25] \\
\hline Aedes cinereus /geminus & 9 & 0.4 & 0 & 0 & 9 & negative & negative & CDC 2005 \\
\hline Culex pipiens pipiens & 3 & 0.1 & 3 & 0 & 0 & negative & negative & [22]; CDC 2005 \\
\hline Coquillettidia sp. & 2 & 0.1 & 2 & 0 & 0 & negative & negative & \\
\hline Ochlerotatus communis & 2 & 0.1 & 2 & 0 & 0 & negative & negative & \\
\hline Total & 2,571 & 100.0 & 1,839 & 39 & 693 & & & \\
\hline
\end{tabular}

Table 3: Summary of all trapped mosquitoes in the Tyrols in summer 2011. Species in bold are evidently competent vectors of West Nile virus, species underlined are evidently competent vectors for Usutu virus.

confirmed by careful investigations of titre movements and the rise of neutralizing antibodies in reconvalescence. Currently, clinical samples are almost exclusively tested by ELISA. Particularly in IgG, we have shown that specifity is not sufficient to identify the causative agent. In the light of our findings, the change of this diagnostic approach appears necessary. This is probably also true for IgM, but unfortunately, in the prospective part of the study, no more acute infections of TBEV could be reported. In areas, where TBEV is wide-spread and immunization coverage of the local population is high, a reliable distinction between cases of TBEV and other flaviviruses is also necessary to avoid corroboration of security and indication of vaccination against TBEV. Our data show three independent factors that give rise to cross-reactive antibodies: 1.) multiple vaccination against different flaviviruses, 2.) excessive booster vaccinations against TBEV and 3.) short time span between serologic test and the last booster vaccination against TBEV. Of these three factors, only excessive booster vaccination can be avoided by titre assessment. The other factors should be recorded in the medical history as they can hinder diagnosis and must be considered when interpreting serologic results.

Clinical monitoring is a powerful tool to detect small scale outbreaks in animals or humans, which are characterized by severe symptoms. However, it is prone to overlook the introduction of strains causing mild or uncharacteristic symptoms. These, however, are most dangerous for the donation of contaminated blood. Seroepidemiologic investigations overcome these limitations but require a sufficient number of infected individuals. Our findings have three consequences for the design of seroepidemiologic studies: our data show that 1.) positive results always require confirmation by SNA, 2.) the cut-off must be assessed carefully by investigating a collective of repeatedly boostered and multiply vaccinated donors and 3.) the vaccination and travel history must be collected thoroughly.

In this study, we have shown that the occurrence of WNV and USUV is below the detection limit of large-scale seroepidemiologic surveys. There is no evidence for WNV or USUV in competent local vectors. At the moment, the only flavivirus causing autochthonous immunoreactions in the local population is TBEV. Human infections with WNV and USUV have been documented in the neighbouring prealpine lowlands [23-25]. The question for the future is whether there are particular factors preventing them from entering alpine valleys.
Temperature has recently been discussed as a limiting factor, but this is rather limiting the presence of susceptible vectors than the circulation of WNV itself [21-25]. Comparisons of temperature curves between our study area and areas of recent outbreaks of WNV as well as the demonstrated occurrence of its vectors indicate that also temperature would support the emergence of the virus in the Tyrols. In the United States, WNV activity is negatively associated with mountainous landscape $[26,27]$. Our findings indicate that this is also true for Europe. The restriction of open water enhances transmission of the virus, most probably because such areas require a closer proximity of potential hosts and vectors. Unlike in eastern Europe, in the Tyrols, times of drought are rare and water is plenty - even at higher sea levels, which are usually considered less suitable for breeding of vectors. This, and not temperature is probably the protective factor in alpine environments. As long as the main ridge of the Alps is covered by glaciers, this situation is not going to change significantly. Global warming alone will probably not open the door for WNV in Tyrol. But we assume that consummation of glaciers and changes in precipitation must be kept in mind when assessing the future risk of WNV circulation. And most notably, if WNV emerges in Western Europe, we will need suitable serologic test systems which are able to differ between different flaviviruses.

\section{Acknowledgement}

The study has been supported by the European Union (Interreg IV), the Austrian federal state of the Tyrol and the Autonomous Province of Bozen/South Tyrol (Italy). Mosquitoes were collected by volunteers among hunters, foresters and members of the Tyrolean Alpine Guards. Data and maps on West Nile virus were kindly provided by the European Centre for Disease Prevention and Contro (ECDC) in Stockholm, Sweden. Furthermore, the authors wish to thank the Austrian Reference Centre for tick-borne encephalitis in Vienna and the RobertKoch Institute, Berlin, Germany for counter-checking critical samples.

\section{References}

1. Reiter $P$ (2010) West Nile virus in Europe: understanding the present to gauge the future. Euro Surveill 15: 19508.

2. Calistri P, Giovannini A, Hubalek Z, Ionescu A, Monaco F, et al. (2010) Epidemiology of west nile in europe and in the mediterranean basin. Open Virol J 4: 29-37.

3. Calzolari M, Bonilauri P, Bellini R, Albieri A, Defilippo F, et al. (2010) Evidence of simultaneous circulation of West Nile and Usutu viruses in mosquitoes sampled in Emilia-Romagna region (Italy) in 2009. PLoS ONE 5: e14324.

4. Bakonyi T, Ivanics E, Erdélyi K, Ursu K, Ferenczi E, et al. (2006) Lineage 1 
Citation: Sonnleitner ST, Simeoni J, Baumgartner R, Zelger R, Prader A, et al. (2013) The Spreading of Flaviviruses over the Continental Divide: a Challenge for Serologic Diagnostics. J Med Microb Diagn S3: 002. doi:10.4172/2161-0703.S3-002

and 2 strains of encephalitic West Nile virus, central Europe. Emerg Infect Dis 12: 618-623.

5. Hubálek Z, Savage HM, Halouzka J, Juricová Z, Sanogo YO, et al. (2000) West Nile virus investigations in South Moravia, Czechland. Viral Immunol 13: 427433

6. Wodak E, Richter S, Bagó Z, Revilla-Fernández S, Weissenböck H, et al. (2011) Detection and molecular analysis of West Nile virus infections in birds of prey in the eastern part of Austria in 2008 and 2009. Vet Microbiol 149: 358-366.

7. Papa A (2012) West Nile virus infections in Greece: an update. Expert Rev Ant Infect Ther 10: 743-750.

8. Barzon L, Pacenti M, Franchin E, Lavezzo E, Martello T, et al. (2012) New endemic West Nile virus lineage 1a in northern Italy, July 2012. Euro Surveill 17: 20231

9. Weissenböck H, Kolodziejek J, Fragner K, Kuhn R, Pfeffer M, et al. (2003) Usutu virus activity in Austria, 2001-2002. Microbes Infect 5: 1132-1136.

10. Chvala S, Bakonyi T, Bukovsky C, Meister T, Brugger K, et al. (2007) Monitoring of Usutu virus activity and spread by using dead bird surveillance in Austria, 2003-2005. Vet Microbiol 122: 237-245.

11. Bakonyi T, Erdélyi K, Ursu K, Ferenczi E, Csörgo T, et al. (2007) Emergence of Usutu virus in Hungary. J Clin Microbiol 45: 3870-3874.

12. Busquets N, Alba A, Allepuz A, Aranda C, Ignacio Nuñez J (2008) Usutu virus sequences in Culex pipiens (Diptera: Culicidae), Spain. Emerg Infect Dis 14: 861-863.

13. Jöst H, Bialonski A, Maus D, Sambri V, Eiden M, et al. (2011) Isolation of usutu virus in Germany. Am J Trop Med Hyg 85: 551-553.

14. Niedrig M, Sonnenberg K, Steinhagen K, Paweska JT (2007) Comparison of ELISA and immunoassays for measurement of IgG and IgM antibody to West Nile virus in human sera against virus neutralisation. J Virol Methods 139: 103105.

15. Moureau G, Temmam S, Gonzalez JP, Charrel RN, Grard G, et al. (2007) A real-time RT-PCR method for the universal detection and identification of flaviviruses. Vector Borne Zoonotic Dis 7: 467-477.
16. Mohrig W (1969) Die Culiciden Deutschlands. Untersuchungen zur Taxonomie Biologie und Ökologie der einheimischen Stechmücken. Parasitologische Schriftenreihe 18. Gustav Fischer Verlag.

17. Becker N, Petric D, Zgomba M, Boase C, Madon M, et al. (2010) Mosquitoes and their control. (2ndedn), Heidelberg: Springer.

18. Calzolari M, Zé-Zé L, Růžek D, Vázquez A, Jeffries C, et al. (2012) Detection of mosquito-only flaviviruses in Europe. J Gen Virol 93: 1215-1225.

19. Hubálek Z, Halouzka J (1999) West Nile fever--a reemerging mosquito-borne viral disease in Europe. Emerg Infect Dis 5: 643-650.

20. Sardelis MR, Turell MJ, Dohm DJ, O'Guinn ML (2001) Vector competence of selected North American Culex and Coquillettidia mosquitoes for West Nile virus. Emerg Infect Dis 7: 1018-1022.

21. Higgs S, Snow K, Gould EA (2004) The potential for West Nile virus to establish outside of its natural range: a consideration of potential mosquito vectors in the United Kingdom. Trans R Soc Trop Med Hyg 98: 82-87.

22. Medlock JM, Snow KR, Leach S (2005) Potential transmission of West Nile virus in the British Isles: an ecological review of candidate mosquito bridge vectors. Med Vet Entomol 19: 2-21.

23. Pecorari M, Longo G, Gennari W, Grottola A, Sabbatini A, et al. (2009) First human case of Usutu virus neuroinvasive infection, Italy, August-September 2009. Euro Surveill 14

24. Cavrini F, Gaibani P, Longo G, Pierro AM, Rossini G, et al. (2009) Usutu virus infection in a patient who underwent orthotropic liver transplantation, Italy, August-September 2009. Euro Surveill 14.

25. Tamba M, Bonilauri P, Bellini R, Calzolari M, Albieri A, et al. (2011) Detection of Usutu virus within a West Nile virus surveillance program in Northern Italy. Vector Borne Zoonotic Dis 11: 551-557.

26. Gibbs SE, Wimberly MC, Madden M, Masour J, Yabsley MJ, et al. (2006 Factors affecting the geographic distribution of West Nile virus in Georgia, USA 2002-2004. Vector Borne Zoonotic Dis 6: 73-82.

27. Roth D, Henry B, Mak S, Fraser M, Taylor M, et al. (2010) West Nile virus range expansion into British Columbia. Emerg Infect Dis 16: 1251-1258. 